\title{
Food Allergy in Children
}

\section{Çocuklarda Besin Alerjisi}

\author{
(i) Ayşe GÜNEŞ BAYIR, id Büşra CAN, iD Şeyma EKINGEN
}

Bezmialem Vakıf University Faculty of Medicine, Department of Nutrition and Dietetics, İstanbul, Turkey

\begin{abstract}
Food allergy, which is defined as an inverse immune response to food proteins, appears to increase gradually in children as a result of studies. It affects $6 \%$ of children and $3-4 \%$ of adults. The role of breast milk in preventing the development of allergies in children is controversial. Allergic reactions caused by food in children cause many symptoms and disorders affecting the gastrointestinal tract, respiratory tract and skin. These symptoms occur by immunoglobulin (Ig)E-mediated or non-IgE-mediated mechanisms. The cornerstone of food allergy treatment is removing foods from the diet by strict elimination method. Along with the genetic tendency, environmental factors can eliminate oral tolerance and cause food allergy. Disease results are affected by the immune system and trigger allergen properties. Foods that cause food allergies are a few, mainly milk, eggs, peanuts, nuts, fish and shellfish. In this review, the level of knowledge about the pathogenesis of the immunological response about most allergens, which are special substances in the protein structure found in foods, has been discussed with studies conducted. Thus, this study will shed light on identifying new immunotherapeutic approaches to allergens.
\end{abstract}

Keywords: Food allergy, allergy in children, IgE, allergens, breast milk

\section{ÖZ}

Besin proteinlerine ters bir immün yanıt olarak tanımlanan besin alerjisi, yapılan çalışmaların sonucunda çocuklarda giderek arttığı görülmektedir. Çocukların \%6'sını ve yetişkinlerin \%34 '́ünü etkilemektedir. Anne sütünün çocuklarda alerji gelişimini önlemesindeki rolü ise tartışmalıdır. Çocuklarda görülen besin kaynaklı alerjik reaksiyonlar gastrointestinal sistemi, solunum yollarını ve deriyi etkileyen birçok semptom ve bozukluklara yol açmaktadır. Bu semptomlar immünoglobulin (Ig)E aracılı ve $\operatorname{IgE}$ aracılı olmayan mekanizmalarla gerçekleşmektedir. Besin alerjisi tedavisinin temel taşı, besinlerin diyetten katı eliminasyon yöntemiyle çıkarılmasıdır. Genetik eğilim ile birlikte çevresel faktörler de oral toleransı ortadan kaldırarak besin alerjisi oluşmasına neden olabilmektedir. Hastalık sonuçları, bağışıklık sistemi ve tetikleyici alerjen özelliklerinden etkilenmektedir. Besin alerjilerine yol açan besinler az sayıda olup başlıcalarını süt, yumurta, yerfıstığı, fındık, balık ve kabuklu deniz ürünleri oluşturmaktadır. Bu derlemede besinlerde bulunan protein yapısındaki özel maddeler olan alerjenlerin çoğu hakkında immünolojik yanıtın patogenezi konusunda bilgi düzeyi yapılan çalışmalarla tartışılmıştır. Böylece, bu çalışma ile alerjenlere karşı yeni immünoterapötik yaklaşımların belirlenmesine ışık tutulacaktır.

Anahtar Sözcükler: Besin alerjisi, çocuklarda alerji, IgE, alerjenler, anne sütü
Address for Correspondence: Ayşe GÜNEŞ BAYIR, Bezmialem Vakıf University Faculty of Medicine, Department of Nutrition and Dietetics, İstanbul, Turkey

E-mail: agunes@bezmialem.edu.tr ORCID ID: orcid.org/0000-0002-9993-7850
Received: 24.01 .2020

Accepted: 21.03 .2020

Cite this article as: Güneş Bayır A, Can B, Ekingen Ş. Food Allergy in Children. Bezmialem Science 2021;9(3):373-9. 


\section{Introduction}

Food allergy in children aged 2-6 years is a health problem that causes changes in social life and diet, which is seen in approximately $4 \%$ of children and families worldwide (1). Food allergy, which is defined as an immune response to food proteins, has become a public health problem as it has been observed to increase in the society as a result of studies (2). While milk and egg are the two most common allergen foods, the most third common allergen food is peanut in Switzerland, wheat in Japan and Germany, and tree nuts in Spain. Based on this situation, it can be said that it differs between countries (1).

Today, the cornerstone of food allergy treatment is the strict elimination of allergen foods from the diet. But; removal of important nutrients such as fish, milk and eggs, which should be included in the nutrition of children aged 2-6, may cause regression in growth-development and nutritional deficiencies in this age group (3).

Allergic reactions due to allergenic foods cause various disorders by affecting the skin and respiratory tract, especially the gastrointestinal system (4). There are 2 types of these reactions that affect immunoglobulin (Ig)E-mediated and non-IgEmediated immune pathways (5). Along with these factors, genetic and environmental factors that eliminate oral tolerance also contribute to reactions related to food allergy (4).

\section{What is a Food Allergy?}

When exposed to a specific food or food group orally or by inhalation, the immune response that is not IgE-mediated, that is IgE-mediated, or that is both, it is called "food allergy" (6). Any protein in food can potentially affect an allergic reaction. The "major allergens" most responsible for these reactions are peanuts, tree nuts, milk, eggs, soy, wheat, shellfish and fish. The progression of food allergy can be very variable. Many individuals with food allergies seen in infancy develop tolerance to these allergenic foods as they get older (7). This situation depends on factors such as food, age of onset of allergy, severity of sensitivity and recognition of allergen components. In general, it is more likely to develop tolerance to allergens in chicken eggs, cow's milk, wheat and soybeans. At the same time, tolerance to allergens such as peanuts, nuts, crustaceans and fish is greater than to buckwheat.

The results of studies on food allergy show that one-fifth of the population reacts negatively to foods. In some countries, it is common in pre-school children and its rate is up to $4-7 \%$ (8). Large-scale epidemiological studies in Japan show that the incidence of food allergy is $5-10 \%$ in infants, $5 \%$ in young children, and $4.5 \%$ in school-age children (7). The changing natural history and disease profile of allergic disease in children and epigenetic effects that may cause hereditary changes, may be due to a complex gene-environment interaction in which the allergenic tendency can be changed or reproduced over generations (6). The immaturity of the intestinal barrier and immune system in infants and young children may contribute to the increased prevalence of allergies in the first few years of life.
Allergic reactions may result in various forms, ranging from urticaria to anaphylactic shock, and death (8). Skin reactions are one of the most common symptoms observed in food allergies. It occurs in $92 \%$ of patients. Respiratory symptoms constitute $33.6 \%$ of these symptoms, mucosal symptoms $28 \%$, digestive symptoms $18.6 \%$ and anaphylaxis $10.4 \%$ (7).

\section{Food Allergy Mechanisms}

In infants and young children, the function of the mucosal barrier, the components of the intestinal barrier and the immune system do not fully reach developmental maturity until 4 years of age (2). Therefore, this maturation may play a role in the incidence of gastrointestinal tract inflammations and food allergies seen in the first years of life. Differences in the digestive capacity of gastritis, including antacid administration, may affect the allergy due to consumed food proteins (9). Urinary lactulose and mannose levels are increased in individuals with food allergies compared to healthy people. All people have low levels of IgE antibodies (10). Persons susceptible to allergic reactions are more likely to produce $\mathrm{IgE}$ antibodies that are specific to environmental antigens such as food, dust, and pollen. While an external antigen is digested by antibodies in normal situations, in case of allergy, macrophages cannot fully digest the antigen and the unabsorbed part passes to lymphocytes with RNA-antigen complexity. This complexity creates a series of reactions within lymphocytes, and as a result antibodies are produced. The antibodies produced, on the other hand, reveal clinical allergy symptoms in some special tissues.

Hypersensitivity reactions are classified into four types (10). These four types of reactions occur independently of each other. The first three types produce antibody-dependent reactions, while in the fourth type, T-lymphocytes and macrophages create reaction. It is involved in asthma and food allergy type 1 reactions. Type 1 reactions are known as anaphylactic (sudden) type sensitivity. In the immune response, excessive or inappropriate reactions may occur against the antigen.

Food-specific IgG, IgM, and IgA antibodies are often found to be low in serum in healthy children without food allergy (4). Food allergen-specific IgG antibodies increase in the first months after consuming a food. Even if the individual continues to consume the food allergen, it often subsides. People with various inflammatory bowel disorders often have high levels of foodspecific IgG and IgM antibodies. However, there is no evidence that these antibodies are pathogenic. As a result of cross-linking of $\operatorname{IgE}$ receptors to mast cells and basophils, the primary and rapid-resulting effect of the allergen is observed in people with allergies (10). These reactions develop due to cross-linking of surface $\operatorname{IgE}$ receptors and mast cells and secretion of substances (mediators) in the cell. The most important mediator for the formation of allergic reactions is histamine.

One of the first developments in the pathogenesis of the allergen is the capture and delivery of the allergen by the antigencontaining cells in the airways or intestinal tract mucosal areas and lymph nodes (11). Specific T-cells for active allergens are present in the circulation of allergic patients. The classical way of $\operatorname{IgE}$ is to bind to T-cell (12). T cells produce CD40 ligand 
(CD40L) in response to an antigenic stimulus and produce $\mathrm{T}$ helper 2 (Th2) type cytokines, interleukin-4 (IL-4) or IL-13 to secrete.

Mast cells play a critical role in allergy (11). Triggering of mast cells and release of previously stored mediators from mast cells are important factors in causing vasodilation, edema formation, or bronchoconstriction during an allergic reaction. Basophils have similar properties to mast cells. It is thought that they often play a minor role in allergic reactions. In addition, basophils, like mast cells, respond to stimuli via $\operatorname{IgE}$ and it is often accepted that they are involved in the effector phase at the onset of allergic reactions.

\section{Food Types That Cause Allergies}

In general, food allergy is seen in $58.1 \%$ of all patients (7). It is mostly seen in children under the age of 1 , at a rate of $88.1 \%$, and as the age increases, the rate of food allergy decreases. Predominant food allergies show differences according to age groups. For example, in children under the age of 1 , chicken eggs $(57.6 \%)$ are in the first place, cow's milk $(24.3 \%)$ is in the second place, and wheat is in the third place, while fruit $(16.5 \%)$ is in the first place in the 4-6 age group, and in the second place is wheat. chicken eggs $(15.6 \%)$ and peanuts $(11.6 \%)$ take the third place. In the adult group ( $\geq 20$ years), wheat $(38 \%)$ is in the first place, fish $(13 \%)$ is in the second place and crustaceans $(10 \%)$ are in the third place.

Many food allergens can cause a reaction when the food is raw, after it has been cooked or even after it has been digested. However, some allergens found in fruits and vegetables cause allergic reactions, especially when these foods are consumed raw (13). Food allergens can also react in case of inhalation of allergy-causing proteins. Cross-reactivity can occur when the allergen in a food has similarity in structure or sequence with a different food allergen or aeroallergen. The likelihood of crossreactive allergens in clinical allergic reactions is highly variable and depends on the type of food.

Proteins that initiate IgE-mediated immune reactions are food allergens (14). Members of the Solanaceae family may cause severe reactions in susceptible individuals. However, with the exception of eggplant (Solanum melongena L.), food allergies are identified due to the consumption of bell peppers, potatoes and tomatoes. On the other hand, some studies explain allergic reactions to eggplant (15). The incidence of allergic reactions is mainly due to the histamine content. A large number of other allergens have been found and some have been found to be heat stable. However, some allergens are heat sensitive and can be destroyed by cooking.

\section{Egg Allergy}

Chicken eggs are one of the most common foods that cause allergies in pediatric patients via $\operatorname{IgE}(16)$. There are more than 20 glycoproteins in glair. Some of these have been identified as major allergens: Ovomucoid, ovaalbumin, conalbumin and lysozyme. Fifty eight children with egg allergy were followed for a period between 7 and 86 months (all children under 2 years of age) (17). Thirty-four children (59\%) gained tolerance to egg allergy. Kaplan-Meier curves showed that the overall tolerance was $50 \%$ at 35 months follow-up. This showed that half of the children were able to tolerate eggs when they were 4 to 4.5 years old. In this process, the best tolerance time was seen as the third year. After the third year, the tolerance decreased. The tolerance ratio was inversely proportional to the $\operatorname{IgE}$ antibody concentration in glair. The most common egg allergy symptoms are skin related symptoms (angioedema, urticaria) in 59\%, gastrointestinal symptoms (diarrhea, vomiting, abdominal pain, bloody stools) in $21 \%$, eczema in $18 \%$, lower respiratory tract symptoms in $10 \%$ (difficulty in breathing, cough, wheezing) and upper respiratory tract symptoms (rhinitis, nasal congestion) in $4 \%$ (18).

\section{Milk Allergy}

Cow's milk allergy in infants and children is the most common type of allergy and its prevalence is between 2\% and 3\% (19). The protein in cow's milk causes the body to show an allergic reaction. Generally, cow's milk allergy becomes evident before 6 months and appears with various symptoms that regress until 6 years of age. About $80 \%$ of children with cow's milk allergy at the age of 3 can tolerate the allergy. Children with cow's milk allergy are often allergic to more than one milk protein (19). Casein constitutes $80 \%$ of cow's milk proteins, and whey constitutes the remaining 20\%. Symptoms occur when $\mathrm{IgE}$ antibodies bind to mast cells due to proteins found in cow's milk, and mast cell degranulation and release of mediators including histamine. In addition to symptoms such as diarrhea and vomiting, anaphylactic shock may also occur (19). In cases where anaphylactic shock occurs, it is absolutely necessary to seek help from the emergency department, as it should be treated with epinephrine. Symptoms such as flushing of the face, swollen throat, itching, increased respiratory effort, and narrowing of the airways occur.

Children with cow's milk allergy may experience vitamin and mineral deficiencies when starting a dairy-free diet (20). Therefore; in order to have a balanced and adequate diet, it is necessary to get help from a dietitian. In particular, vitamin D has a very important place in bone development in children of this age group. As a result of eliminating cow's milk products from the diet, it may be necessary to take supplements because there may be a deficiency of vitamins and minerals in milk such as vitamin D, riboflavin and calcium. It is known that the cow's milk allergy type with rapid symptoms is IgE-mediated. Urticaria, hives, sore throat, angioedema, coughing, vomiting, shortness of breath and anaphylaxis are the main symptoms (19). Reactions with slower symptoms are related with non-IgE-mediated cow's milk allergy. Its symptoms are diarrhea, hematochezia, colic, and abdominal cramps.

\section{Peanut Allergy}

The rate of peanut allergy in children increased by $0.4 \%$ in 1997 , $0.8 \%$ in 2002 , and $1.4 \%$ in 2008 compared to the previous years (21). The reason for this increase is due to problems such as the extra allergen in the roasted peanut forms, the early exposure to peanuts when the immune system is not fully mature, and the 
fact that peanuts are not included in the diet. Peanut allergy can be lifelong, often severe and fatal. The severity and persistence of allergies also increase over time (22). Factors that can lead to a fatal outcome include the diagnosis of asthma, a delay in the administration of epinephrine, and the presence of peanuts at meals (23). Peanut allergy symptoms usually develop a few minutes after consuming a small amount of peanuts. These can affect the skin, cardiovascular, gastrointestinal, genitourinary or respiratory systems. In fatal cases, progressive upper and lower respiratory tract symptoms, hypertension, and arrhythmia typically develop. In one study, $89 \%$ of the reactions occur in the skin, $52 \%$ in the respiratory tract, and $34 \%$ in the gastrointestinal tract. There is no known cure for peanut allergy (24). It is common for children with allergies to accidentally eat peanuts. If a person with a peanut allergy accidentally consumes a peanut-containing food, serious allergic reactions develop. Epinephrine and antihistamines are given to patients as an emergency treatment plan.

\section{Pollen Allergy}

Pollen in the environment is becoming a growing problem for people with pollen allergies (25). Allergenic pollens are emitted from anemophile trees. The feeding habits of the bee affect the plant diversity or weather conditions in a particular region. These allergenic pollens can be found in all bee products. It is even known as an important component of honey and can determine the quality and type of honey. Pollen can enter honey in different ways. The amount of pollen may differ according to the type and collection period. Pollen allergens in honey can cause allergic reactions. However, pollen-induced allergy is rarely seen and can cause anaphylactic reactions. Climatic and weather conditions, biological characteristics of plants or environmental conditions are determinants for pollen abundance (25). Therefore, pollen concentrations in honey vary from year to year. Often, pollen concentrations and prolonged pollen season can also increase the severity of symptoms. Mostly, patients are affected by climate change (66\%) (26).

\section{Oral Allergy Syndrome}

Oral allergy syndrome is a form of food allergy due to uncooked foods, that often causes allergic symptoms limited to the oral mucosa (27). Most IgE epitopes in foods recognized by patients with oral allergy syndrome may be the same as pollen allergens (28). Therefore, pollen allergens may be responsible for the emergence and maintenance of the oral allergy syndrome. In oral allergy syndrome, oral pharyngeal symptoms first appear after consumption of fruits and vegetables (29). Systemic symptoms can be seen in $8.7 \%$ of the patients and anaphylactic shock in $1.7 \%$. Localized oral symptoms such as numbness in the lips or mouth, itching, tingling and swelling in the lips, tongue, palate, and pharynx are mostly observed (30). There are various risk factors for oral allergy syndrome (30). Patients with symptomatic pollen allergy have a higher risk of oral allergy syndrome than patients with only pollen sensitivity and who are asymptomatic.
Allergen distribution is not the same in all parts of the fruit or vegetable (30). There is much more allergen in the peel of apples and peaches. In a small-scale study; while $40 \%$ of patients with apple and pear allergy could tolerate the fleshy part of the fruit, allergy occured when the whole fruit was eaten. Elimination of known allergenic foods from the diet is usually the first treatment that comes to mind for oral allergy syndrome (31). Restricting all other fresh vegetables and fruits in the same plant family or crossreacting with the same pollen is also considered unnecessary.

\section{Wheat Allergy}

One of the most common childhood food allergies is wheat allergy, affecting $0.4 \%$ of children (32). Wheat contains four classes of allergenic proteins (33). These are albumins, globulins, gliadin, and glutenins. Gliadin and glutenin make up $85 \%$ of wheat protein (34). Symptoms due to IgE-mediated reactions may develop, usually 2 hours after consuming wheat. As a result of digesting the proteins in wheat, bronchial obstruction, urticaria, angioedema, nausea, abdominal pain or systemic anaphylaxis may occur. It is known that the prognosis of IgE-mediated wheat allergy in children is good. Patients with anaphylaxis before the age of 3 and patients with high wheat-specific $\operatorname{IgE}$ antibodies seem to be at risk of being more persistent (1). Since it is not necessary to limit the consumption of foods containing barley and rye in the treatment of wheat allergy, it is essential to avoid foods containing wheat, which will be less restricted in wheat allergy than in celiac disease (35). Celiac disease is a lifelong food allergy that is not associated with $\operatorname{IgE}$ (36). It is mostly seen in children aged 6-12 years. Besides wheat; there is also sensitivity to gluten in barley and rye. As a result of the toxic effect of gluten in the intestines, the digestive and absorption activities of the intestines are impaired. Diarrhea, frequent defecation, swelling in the abdomen, malnutrition, and as a result, developmental delay occur. The disease is diagnosed by small intestinal mucosal biopsy, blood and stool tests. The treatment of Celiac disease is still not found today. A gluten-free diet should be applied as an elimination diet. Parents should have their child's allergy status checked regularly. Most likely, children will recover from this allergy and may no longer need an elimination diet, a gluten-free diet.

\section{Seafood Allergy}

More than one-third of children today show an allergic reaction to fish species (37). A retrospective study among 2999 children with food allergies in a clinic in Australia showed a 5.6\% prevalence of fish allergy (38). Tuna and salmon were the most common fish species causing allergy. Another study conducted in Singapore confirmed that $13 \%$ of 227 children with food sensitivities had a significant sensitivity to fish. Interestingly, it was observed for the first time in Asian societies that fish consumption started very early, at about 7 months (37). Although heat is thought to increase the allergenicity of some fish allergens, commercial heating procedures used in producing canned fish appear to have a different effect on fish proteins (38). A recent descriptive study from Australia showed that more than $20 \%$ of children allergic to tuna and salmon could tolerate canned fish. 


\section{Breast Milk and Food Allergy}

Due to the increasing rates of allergic disease in developed countries, there is interest in the potential effects of breast milk in modulating immune responses (39). There are different mechanical ways that breast milk can protect against allergic disease. Breast milk contains bioactive factors, regulatory cytokine converting growth factor- $\beta$ (TGF- $\beta$ ), secretory $\operatorname{IgA}$ antibodies and innate immune receptor soluble CD14 (sCD14). TGF- $\beta$ in breast milk is required for the initiation of $\operatorname{IgA}$ production in newborn infants and induces mucosal tolerance to allergens. There are controversial results about the role of infants' consumption of breast milk in the prevention of allergy development (40). This is because there are differences in the composition of breast milk. For example; it is thought that high IgA and TGF- $\beta$ levels in breast milk provide protection against the development of allergic diseases in some studies, while there is no significant relationship between breast milk TGF- $\beta$ and atopic risk in others. Breast milk contains various cytokines and chemokines such as TGF-IL, IL-10, IL-4, RANTES, and IL-8 that are involved in allergic reactions (41). A few of these factors differ between allergic and non-allergic mothers. While high IgE levels were detected with breastfeeding in the children of mothers with high IgE levels, low antibody levels were observed in children of mothers with low IgE levels (41).

\section{Diagnostic Methods of Food Allergy}

Diagnosing food allergies allows knowing which mechanism is involved and identifying potential food triggers (42). Clinical history, skin tests, or serum-specific IgE tests alone or in combination give results between $50 \%$ and $100 \%$ (43). The first line tests to assess IgE sensitivity for food allergens are; in vivo skin tests and serum-specific IgE tests, but these tests or patient history cannot always accurately diagnose food allergy (44). Endoscopy and biopsy are required to diagnose some clinical findings such as food-borne enteropathies.

\section{Specific IgE: Skin Tests and In Vitro Test}

It is performed to determine sensitivity to suspected food allergens and to evaluate cross-sensitivity to the relevant food (45). Serum specific IgE or skin prick tests, although not standardized, are cited as scientifically valid tests. Detailed clinical history should guide the selection of tests (46). Skin tests should only be performed by trained healthcare professionals who can interpret results and manage potential adverse reactions. These tests are performed on the forearm or upper back. While performing and interpreting skin tests, there are variables that should be considered such as age, gender, test site and timing. While these tests show high performance in allergens such as eggs, milk, fish, shrimp, nuts, peanuts, they do not have high performance in allergens such as soy and wheat (47). Placebo (single/double) studies can be conducted on difficulties occurring after oral food consumption (48). Especially; the blinded placebo test is considered the gold standard for the diagnosis of food allergy. The double-blind placebo-controlled food challenge is more difficult due to difficulty in sourcing and time consuming (42).
In patients with suspected psychological symptoms or atopic eczema, the double-blind placebo-controlled test outperforms the oral nutritional challenge comparison. Certain portions of the food protein recognized by the $\operatorname{IgE}$ antibody have been identified for some food allergens (2). In molecular or serological diagnostic tests, specific IgE antibodies can be measured against individual allergenic molecules from foods that have the potential to improve the specificity of the serum $\operatorname{IgE}$ test and the specificity of the selected food (49). This can be performed in single test formats or in a micropattern to test multiple purified allergens at the same time. There are a number of tests whose accuracy has not been fully proven in food allergy (50). These tests are kinesiology, iridology, bioresonance, hair analysis, cytotoxic test, IgE and IgG4 determination. Since these tests have not been confirmed so far, their use in the diagnosis of food allergy is not recommended.

\section{Conclusion}

Food allergy is now recognized as a problem worldwide, especially in children, and is increasing like other atopic disorders. In recent years, much attention has been paid to research on food allergy. Food allergens cause both acute and chronic diseases and may cause some negative effects on quality of life. Depending on the severity of the allergic reaction, the result can be fatal. Clinical studies have caused changes to be made in early nutrition guidelines for the prevention of food allergy. More information needs to be learned about the immune mechanisms of oral tolerance. New diagnostic tools can be developed to more accurately identify food allergens. In general, clinical trials of potential therapy in children are being conducted. Whether these treatments will cause only short-term desensitization or long-term tolerance is under investigation, and these studies may provide a better understanding of tolerance mechanisms. More specific diagnostic tests and more effective forms of treatment are still needed in this area.

Peer-review: Externally peer reviewed.

\section{Authorship Contributions}

Concept: A.G.B., Design: A.G.B., Data Collection or Processing: B.C., Ş.E., Analysis or Interpretation: A.G.B., B.C., Ş.E., Literature Search: B.C., Ş.E., Writing: A.G.B., B.C., Ş.E.

Conflict of Interest: No conflict of interest was declared by the authors.

Financial Disclosure: The authors declared that this study received no financial support.

\section{References}

1. Longo G, Berti I, Burks AW, Krauss B, Barbi E. IgE-mediated food allergy in children. Lancet 2013;382:1656-64.

2. Sicherer SH, Sampson HA. 9. Food allergy. J Allergy Clin Immunol 2006;117:470-5.

3. Pavić I, Kolaček S. Growth of Children with Food Allergy . Horm Res Paediatr 2017;88:91-100. 
4. Sicherer SH, Sampson HA. Food allergy. J Allergy Clin Immunol 2010;125:116-25.

5. Tordesillas L, Berin MC, Sampson HA. Immunology of Food Allergy. Immunity 2017;47:32-50.

6. Devdas JM, Mckie C, Fox AT, Ratageri VH. Food Allergy in Children: An Overview. Indian J Pediatr 2018;85:369-74.

7. Ebisawa M, Ito K, Fujisawa T; Committee for Japanese Pediatric Guideline for Food Allergy, The Japanese Society of Pediatric Allergy and Clinical Immunology, The Japanese Society of Allergology. Japanese guidelines for food allergy 2017. Allergol Int 2017;66:24864.

8. Turnbull JL, Adams HN, Gorard DA. Review article: the diagnosis and management of food allergy and food intolerances. Aliment Pharmacol Ther 2015;41:3-25.

9. Moore LE, Stewart PH, deShazo RD. Food Allergy: What We Know Now. Am J Med Sci 2017;353:353-66.

10. Karakılıç M, Suna S, Tamer CE, Çopur ÖU. Gıda Alerjisi Reaksiyonları. Uludağ Üniversitesi Ziraat Fakültesi Dergisi 2014;28:73-82.

11. Kraneveld AD, Sagar S, Garssen J, Folkerts G. The two faces of mast cells in food allergy and allergic asthma: the possible concept of Yin Yang. Biochim Biophys Acta 2012;1822:93-9.

12. Geha RS, Jabara HH, Brodeur SR. The regulation of immunoglobulin E class-switch recombination. Nat Rev Immunol 2003;3:721-32.

13. Burks AW, Tang M, Sicherer S, Muraro A, Eigenmann PA, Ebisawa M, et al. ICON: food allergy. J Allergy Clin Immunol 2012;129:90620.

14. Harish Babu BN, Wilfred A, Venkatesh YP. Emerging food allergens: Identification of polyphenol oxidase as an important allergen in eggplant (Solanum melongena L.). Immunobiology 2017;222:15563.

15. Hoseini-Alfatemi SM, Bayry J, Sharifi-Rad J. IgE response to two new allergen proteins of Solanum melongena L. (eggplant). Immunol Lett 2015;168:268-70.

16. Ando H, Movérare R, Kondo Y, Tsuge I, Tanaka A, Borres MP, et al. Utility of ovomucoid-specific IgE concentrations in predicting symptomatic egg allergy. J Allergy Clin Immunol 2008;122:583-8.

17. Boyano-Martínez T, García-Ara C, Díaz-Pena JM, Martín-Esteban $\mathrm{M}$. Prediction of tolerance on the basis of quantification of egg whitespecific IgE antibodies in children with egg allergy. J Allergy Clin Immunol 2002;110:304-9.

18. Savage JH, Matsui EC, Skripak JM, Wood RA. The natural history of egg allergy. J Allergy Clin Immunol 2007;120:1413-7.

19. Edwards CW, Younus MA. Cow Milk Allergy. Book from StatPearls Publishing, Treasure Island (FL) 2019.

20. Pensabene L, Salvatore S, D'Auria E, Parisi F, Concolino D, Borrelli O, et al. Cow's Milk Protein Allergy in Infancy: A Risk Factor for Functional Gastrointestinal Disorders in Children? Nutrients 2018;10:1716.

21. Sicherer SH, Muñoz-Furlong A, Godbold JH, Sampson HA. US prevalence of self-reported peanut, tree nut, and sesame allergy: 11year follow-up. J Allergy Clin Immunol 2010;125:1322-6.
22. Sicherer SH, Sampson HA. Peanut allergy: emerging concepts and approaches for an apparent epidemic. J Allergy Clin Immunol 2007;120:491-503.

23. Al-Ahmed N, Alsowaidi S, Vadas P. Peanut allergy: an overview. Allergy Asthma Clin Immunol 2008;4:139-43.

24. Nurmatov U, Venderbosch I, Devereux G, Simons FE, Sheikh A. Allergen-specific oral immunotherapy for peanut allergy. Cochrane Database Syst Rev 2012;(9):CD009014.

25. Sauliene I, Sukiene L, Noreikaite-Merkeliene A, Pileckas V. The comparison of pollen abundance in air and honey samples. Acta Agrobotanica 2015;68:391-8.

26. Lake IR, Jones NR, Agnew M, Goodess CM, Giorgi F, HamaouiLaguel L, et al. Climate Change and Future Pollen Allergy in Europe. Environ Health Perspect 2017;125:385-91.

27. Ta VA, Kelso JM, White AA, Scott DR, Chin WK, Wineinger N. Differential skin test reactivity to pollens in pollen food allergy syndrome versus allergic rhinitis. Journal of Allergy and Clinical Immunology 2015;135:AB37.

28. Kazemi-Shirazi L, Pauli G, Purohit A, Spitzauer S, Fröschl R, Hoffmann-Sommergruber K, et al. Quantitative IgE inhibition experiments with purified recombinant allergens indicate pollenderived allergens as the sensitizing agents responsible for many forms of plant food allergy. J Allergy Clin Immunol 2000;105:116-25.

29. Webber CM, England RW. Oral allergy syndrome: a clinical, diagnostic, and therapeutic challenge. Ann Allergy Asthma Immunol 2010;104:101-8.

30. Kar Kurt Ö, Erkoçoğlu M, Kurt M. Polen gıda allerjisi Sendromu [Pollen food allergy syndrome]. Tuberk Toraks 2017;65:138-45.

31. Price A, Ramachandran S, Smith GP, Stevenson ML, Pomeranz MK, Cohen DE. Oral allergy syndrome (pollen-food allergy syndrome). Dermatitis 2015;26:78-88.

32. Keet CA, Matsui EC, Dhillon G, Lenehan P, Paterakis M, Wood RA. The natural history of wheat allergy. Ann Allergy Asthma Immunol 2009;102:410-5.

33. Ricci G, Andreozzi L, Cipriani F, Giannetti A, Gallucci M, Caffarelli C. Wheat Allergy in Children: A Comprehensive Update. Medicina (Kaunas) 2019;55:400.

34. Tatham AS, Shewry PR. Allergens to wheat and related cereals. Clin Exp Allergy 2008;38:1712-26.

35. Pietzak M. Celiac disease, wheat allergy, and gluten sensitivity: when gluten free is not a fad. JPEN J Parenter Enteral Nutr 2012;36:68-75.

36. Güneş Bayır A. Gıda Hassasiyeti (10. Bölüm), Eds: Eker H.H. ve Güneş Bayır A. Sağlıklı Beslenme. Nobel Tıp Kitabevi; 2015;37-8.

37. Sicherer SH, Muñoz-Furlong A, Sampson HA. Prevalence of seafood allergy in the United States determined by a random telephone survey. J Allergy Clin Immunol 2004;114:159-65.

38. Turner P, Ng I, Kemp A, Campbell D. Seafood allergy in children: a descriptive study. Ann Allergy Asthma Immunol 2011;106:494-501.

39. Ismail IH, Licciardi PV, Oppedisano F, Boyle RJ, Tang ML. Relationship between breast milk sCD 14, TGF- $\beta 1$ and total I g A in the first month and development of eczema during infancy. Pediatric Allergy and Immunology 2013;24:352-60. 
40. Tomicić S, Johansson G, Voor T, Björkstén B, Böttcher MF, Jenmalm MC. Breast milk cytokine and IgA composition differ in Estonian and Swedish mothers-relationship to microbial pressure and infant allergy. Pediatr Res 2010;68:330-4.

41. Böttcher MF, Jenmalm MC. Breastfeeding and the development of atopic disease during childhood. Clin Exp Allergy 2002;32:159-61.

42. Muraro A, Werfel T, Hoffmann-Sommergruber K, Roberts G, Beyer $\mathrm{K}$, Bindslev-Jensen $\mathrm{C}$, et al. EAACI food allergy and anaphylaxis guidelines: diagnosis and management of food allergy. Allergy 2014;69:1008-25.

43. Sampson HA. Food allergy--accurately identifying clinical reactivity. Allergy 2005;60:19-24.

44. Sackeyfio A, Senthinathan A, Kandaswamy P, Barry PW, Shaw B, Baker $\mathrm{M}$, et al. Diagnosis and assessment of food allergy in children and young people: summary of NICE guidance. BMJ 2011;342:d747.

45. Heinzerling LM, Burbach GJ, Edenharter G, Bachert C, BindslevJensen C, Bonini S, et al. GA(2)LEN skin test study I: GA(2)LEN harmonization of skin prick testing: novel sensitization patterns for inhalant allergens in Europe. Allergy 2009;64:1498-506.

46. Konstantinou GN, Bousquet PJ, Zuberbier T, Papadopoulos NG. The longest wheal diameter is the optimal measurement for the evaluation of skin prick tests. Int Arch Allergy Immunol 2010;151:343-5.

47. Soares-Weiser K, Takwoingi Y, Panesar SS, Muraro A, Werfel T, Hoffmann-Sommergruber K, et al. The diagnosis of food allergy: a systematic review and meta-analysis. Allergy 2014;69:76-86.

48. Niggemann B, Lange L, Finger A, Ziegert M, Müller V, Beyer $K$. Accurate oral food challenge requires a cumulative dose on a subsequent day. J Allergy Clin Immunol 2012;130:261-3.

49. Glaumann S, Nopp A, Johansson SG, Rudengren M, Borres MP, Nilsson C. Basophil allergen threshold sensitivity, CD-sens, IgEsensitization and DBPCFC in peanut-sensitized children. Allergy 2012;67:242-7.

50. Niggemann B, Grüber C. Unproven diagnostic procedures in IgEmediated allergic diseases. Allergy 2004;59:806-8. 